\title{
Reply to the Letter to the Editor
}

\section{Adverse Reactions of Artificial Bone Graft Substitutes: Lessons Learned From Using Tricalcium Phosphate geneX ${ }^{\circledR}$}

\author{
Joerg Friesenbichler MD, Werner Maurer-Ertl MD, Patrick Sadoghi MD, \\ Ulrike Pirker-Fruehauf MD, Koppany Bodo MD, Andreas Leithner MD
}

Received: 2 December 2013/Accepted: 2 December 2013/Published online: 10 December 2013

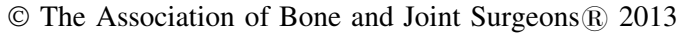

\section{To the editor,}

We appreciate the authors' serious concern for the safety of their product, and confirm the mentioned constructive site visit. However, in order to elucidate our perspective, we once again report a $16 \%$ complication rate following curettage plus filling the bone void with gene $\mathrm{X}^{\circledR}$, which is not acceptable for a new medical device.

The previously reported complications for allografts include nonunion, delayed bone healing, infection, and

(RE: Friesenbichler J, Maurer-Ertl W, Sadoghi P, Pirker-Fruehauf U, Bodo K, Leithner A. Adverse Reactions of Artificial Bone Graft Substitutes: Lessons Learned From Using Tricalcium Phosphate geneX $^{\mathbb{R}}$. [Published online ahead of print September 28, 2013]. Clin Orthop Relat Res. DOI: 10.1007/s11999-013-3305-z.)

Each author certifies that he or she, or a member of his or her immediate family, has no funding or commercial associations (eg, consultancies, stock ownership, equity interest, patent/licensing arrangements, etc) that might pose a conflict of interest in connection with the submitted article.

All ICMJE Conflict of Interest Forms for authors and Clinical Orthopaedics and Related Research editors and board members are on file with the publication and can be viewed on request. Clinical Orthopaedics and Related Research neither advocates nor endorses the use of any treatment, drug, or device. Readers are encouraged to always seek additional information, including FDAapproval status, of any drug or device prior to clinical use.

Each author certifies that his or her institution approved the reporting of this case report, that all investigations were conducted in conformity with ethical principles of research, and that informed consent for participation in the study was obtained.

J. Friesenbichler, W. Maurer-Ertl, P. Sadoghi ( $₫)$,

U. Pirker-Fruehauf, A. Leithner

Department of Orthopaedic Surgery, Medical University

of Graz, 8036 Graz, Styria, Austria

e-mail: patrick.sadoghi@medunigraz.at; patricksadoghi@gmx.at

K. Bodo

Institute of Pathology, Medical University of Graz, Graz, Austria plate breakage. The complication rate of nearly $30 \%[1,3]$ is different from the rate currently reported with the use of geneX $\mathrm{X}^{\mathbb{R}}$ in our series.

It is correct that in the current series, one patient used Vitoss $^{\mathrm{TM}}$ (Stryker Orthopaedics, Mahwah, NJ, USA) combined with gene ${ }^{\circledR}$ and allograft struts to refill the bony void after the curettage of a relapsed juvenile bone cyst of the humerus (patient 30). It is also correct, that the instructions for use advise against this approach. Nevertheless, we do not believe that the combination of these bone graft substitutes caused the cystic formation due to the relation of the substitutes with a relatively large mass $(45 \mathrm{cc})$ of geneX ${ }^{\circledR}$ combined with only 5 cc of Vitoss ${ }^{\mathrm{TM}}$. Additionally, researchers identified a second case of a cystic formation in the soft tissue without using other bone graft materials. Resorption of the sulfate component of geneX ${ }^{\mathbb{R}}$ may induce a chemical reaction leading to the development of gas, but this fact needs further investigation. In 46 cases, we have yet to encounter cystic formations or severe inflammation when using Vitoss ${ }^{\mathrm{TM}}$, according to an unpublished prospective controlled trial.

We placed the allograft inside the bony defect before filling the resting space with gene $\mathrm{X}^{\circledR}$. Overfilling and pressurizing is rarely possible in such large bone defects with a long cortical bone window. Additionally, "sealing" or closure of the bone window is not possible in most of the tumor cases.

We further want to clarify that we have read the comments made regarding the paper by Saadoun et al. [4] as well as the published response [2] and the clarification statement published by the authors [5]. We do not believe these comments are relevant for the current manuscript and that the information does not change the outcome of our reported series. The comments of Saadoun et al. concerning complication rates of gene ${ }^{\circledR}$ were used as templates [5], and have been marked as citation. 
In conclusion, we encountered severe complications after using gene $\mathrm{X}^{\circledR}$, which we have not reported in the literature before. We suppose that these side effects could be caused by the calcium sulfate component of the product, a decrease of the local $\mathrm{pH}$ value, the product becoming fluid-like some days after its initial hardening, or the invasion of inflammatory cells.

\section{References}

1. Bullens PHJ, Minderhoud NM, de Waal Malefijt MC, Veth RPH, Buma P, Schreuder HWB. Survival of massive allografts in segmental oncological bone defect reconstructions. Int Orthop. 2009;33:757-760.

2. Fitzer S, Cooper JJ. Biocomposites Ltd response. J Neurol Neurosurg Psychiatry. 2011;82:e3.

3. Johnson LJ, Clayer M. Aqueous calcium sulphate as bone graft for voids following open curettage of bone tumours. ANZ J Surg. 2013;83:564-570.

4. Saadoun S, Macdonald C, Bell BA, Papadopoulos MC. Dangers of bone graft substitutes: lessons from using GeneX ${ }^{\mathbb{R}}$. J Neurol Neurosurg Psychiatry. 2011;82:e3.

5. Saadoun S, Macdonald C, Bell BA, Papadopoulos MC. Dangers of bone graft substitutes: lessons from using GeneX $^{\circledR}$. Clarification. J Neurol Neurosurg Psychiatry. 2011; 82:e3. 